\title{
ACCOUNTING OF FRANCHISING ACTIVITIES OF TOURIST ENTERPRISES OF UKRAINE
}

\author{
Oleh VYSOCHAN* \\ Lviv Polytechnic National University, Department of Accounting and Analysis, Lviv, Ukraine, e-mail: oleh.s.vysochan@lpnu.ua \\ Olha VYSOCHAN \\ Lviv Polytechnic National University, Department of Accounting and Analysis, Lviv, Ukraine, e-mail: olha.o.vysochan@lpnu.ua
}

Volodymyr CHUBAI

Lviv Polytechnic National University, Department of Accounting and Analysis, Lviv, Ukraine, e-mail: volodymyr.m.chubai@lpnu.ua

\author{
Vasyl HYK
}

Lviv Polytechnic National University, Department of Accounting and Analysis, Lviv, Ukraine, e-mail: vasyl.v.hyk@lpnu.ua

Citation: Vysochan, O., Vysochan, O., Chubai, V., \& Hyk, V. (2022). ACCOUNTING OF FRANCHISING ACTIVITIES OF
TOURIST ENTERPRISES OF UKRAINE. GeoJournal of Tourism and Geosites, 40(1), 71-78. https://doi.org/10.30892/gtg.40108-804

\begin{abstract}
The article is devoted to solving several problems in the methodology of accounting for travel franchising. The methodology is based on a system of binding relationships formed between the franchisor and the franchisee to account for the accrual of a one-time/lump sum and royalty/periodic service fee. Influence on the methodology of accounting for franchising operations in tourism is the understanding of the essence of franchising as an agreement, a special type of business, marketing system, forms of business cooperation, forms of organization and business, delivery of services to end-users. The result of the need to gradually attribute the lump sum to expenses or income of the reporting period during the term of the agreement is the use of the mechanism of redistribution through the accounts of expenses/income of future periods.
\end{abstract}

Key words: accounting, tourism, franchising, franchise, franchisor, franchisees

\section{INTRODUCTION}

The search for effective organizational and legal forms of entrepreneurial activity by small and medium-sized enterprises, which would best meet modern business challenges, has led to the popularity of franchising networks in Ukraine and the world. Franchising can not be called an innovative form of business relations (in fact, this concept is identical to a commercial concession in domestic practice, while in English-speaking countries it dates back to the Late Middle Ages), but in terms of building rational (cost-effective) partnerships relations between enterprises on the provision of some for commercial use of the brand, corporate standards and methods of work, marketing strategies, etc. to others, such relations have gained new meaning. Franchising is direct evidence that partnerships between business entities operating in the same industry, including tourism, are not only possible but also potentially mutually beneficial franchisors expand the scope and geography of activities, franchisees - minimize business risks and investments; both receive additional income, including and due to the synergistic effect. Many years of experience in the use of franchising networks in countries with developed economies have already proven the high level of business efficiency of this way of developing the tourism business. The idea of expanding new markets by transferring new concepts to other units allows all participants in this process to reach a consistently high level of profitability in a relatively short period.

In addition, understanding the benefits of using franchising networks is only a motivator for making rational management decisions at various levels, information support which, especially regarding the profitability of the franchising concept from the franchisor (Gallini and Lutz, 1992), should be effectively established accounting system in tourism enterprises - potential network participants. Franchising forms a system of relationships between the participants in the franchising agreement to achieve their common goals. At the same time, neither party loses legal independence and the right to make management decisions independently, assessing the effectiveness of activities using an accounting approach (Kaufmann et al., 2000; Nurwulan et al., 2013; Sisea, 2013; Tsenkler and Nemesh, 2019; Kim and Lee, 2020; Sadeh and Kacker, 2020; Bardash, 2021). In terms of the spread of franchising schemes, the tourism business is inferior to such leaders in related industries as fast-food restaurants and the hotel industry, but the pace of development allows us to predict the continued demand for the franchise in this area. There are more than a dozen well-known tourist franchising networks in Ukraine. Among them: "TUI", "Coral Travel”, "TEZ TOUR Travel Agency", "Join UP! Travel Agency","Poihaly z namy","Feieriia mandriv","Sonata","More turiv","Traident Hit","Na Kanikuly" and others.

Given the above, in the article we ask questions, the answers to which, we believe, will be important for improving the accounting of enterprises in the field of tourism in Ukraine:

\footnotetext{
* Corresponding author
} 
RQ1: Can a franchise be considered a special type of intangible asset for accounting purposes?

RQ2: Is it methodologically and practically appropriate for the franchisor and the franchisee to use the mechanism of income and expenses of future periods for the redistribution of lump-sum contributions for different reporting periods?

RQ3: What nomenclature of accounting sub-accounts is most informative to reflect the income and expenses of the period arising in the process of franchising by tourism enterprises?

\section{LITERATURE REVIEW}

The rapid development of research in the field of accounting for franchising began in the early 70 s of the last century. The research was of an applied nature, and Archibald E. MacKay's article in The Journal of Accountancy was even considered by the Securities and Exchange Commission (SEC) to be the equivalent of the Opinion Accounting Principles Board (APB), which in itself was quite rare in accounting regulation practice (Zeff, 2011). Subsequently, the issue of accounting for franchising has increasingly begun to be thoroughly considered in the academic literature (Kieso et al., 2011). This is primarily due to the active implementation of the practice of franchising in small businesses in the United States in the 60s. For a long time, this business model has remained leading for businesses in many sectors of the economy, including the restaurant industry and tourism (Bunea-Bontas and Petre, 2009; Czakon, 2012; Varotto and Aureliano-Silva, 2017; Rosado-Serrano et al., 2018; Elango, 2019; Alon et al., 2021; Ghani et al., 2021).

The accounting nuances of the settlement relations between the participants of the franchising network, which are based on contractual terms, have always caused methodological difficulties. This is mainly due to debatable allocation of the franchise to intangible assets, consistency of income and expenses from franchising operations over time, recognition and distribution of income in the form of royalties (especially about a franchising agreement with an unlimited duration), use of expense accounts and deferred income for long-term franchising operations, accounting features of the reflection of periodic payments, which depend on the amount of income received by the franchisee, etc. The vast majority of works by Ukrainian economists are devoted to solving.

In Ukraine, the first thorough publications on franchising began to appear in the late 2000s, due to the legal regulation of the term "commercial concession" in two basic regulations governing civil and commercial relations - the Civil and Commercial Codes, which came into force on January 1, 2004. In domestic realities the concepts of "commercial concession" and "franchising" have a similar economic and legal meaning. Already in the last decade, accounting for franchising has become one of the priority areas in accounting research in general (Momot and Ovdiy, 2010; Lysa and Andrushko, 2013; Makoviychuk, 2013; Romanchuk et al., 2014; Serpeninova, 2014; Tsyutsyak, 2014; Makarovych et al., 2015; Kravchuk and Spivak, 2017), incl. using automated systems (Marik and Komlichenko, 2014; Vysochan et al., 2021b) and in the tourism business in particular (Kuryshko, 2014; Vysochan, 2014; Shevchuk, 2017; Vysochan et al., 2021a).

Despite the importance of accounting procedures for establishing the effectiveness of the relationship between the franchisor and the franchisee, there is a certain lack of thorough publications on this topic (Combs et al., 2011), franchising research lags behind the development of franchising in practice (Diez de Castro et al., 2004). Given the contribution of researchers to domestic accounting science and based on the dynamic development of modern economic scientific thought, we consider it necessary to deepen the existing developments of a methodological nature regarding franchise accounting, as well as accrual and payment (receipt) of lump sum and periodic royalties business.

Thus, the main purpose of our study is to develop a nomenclature of accounting records to reflect in the accounts of franchise transactions in the business of Ukrainian companies - franchisors and franchisees, taking into account the intangible nature of the franchise and redistribution of lump sums through future income and expenses.

\section{MATERIALS AND METHODS}

This study used quantitative data on franchising of companies (in particular, the number of franchisors, the number of franchisees and own facilities in franchise companies), obtained by the analytical company Franchise Group, to assess this market segment and determine the prospects for its development in Ukraine since 2001.

The data allow us to understand the trend of changes in the presented indicators in the accounting perspective in chronological order, to assess the causal links of the growing interest of Ukrainian companies in the business strategy of franchising and assess the relevance of research in this area in terms of accounting.

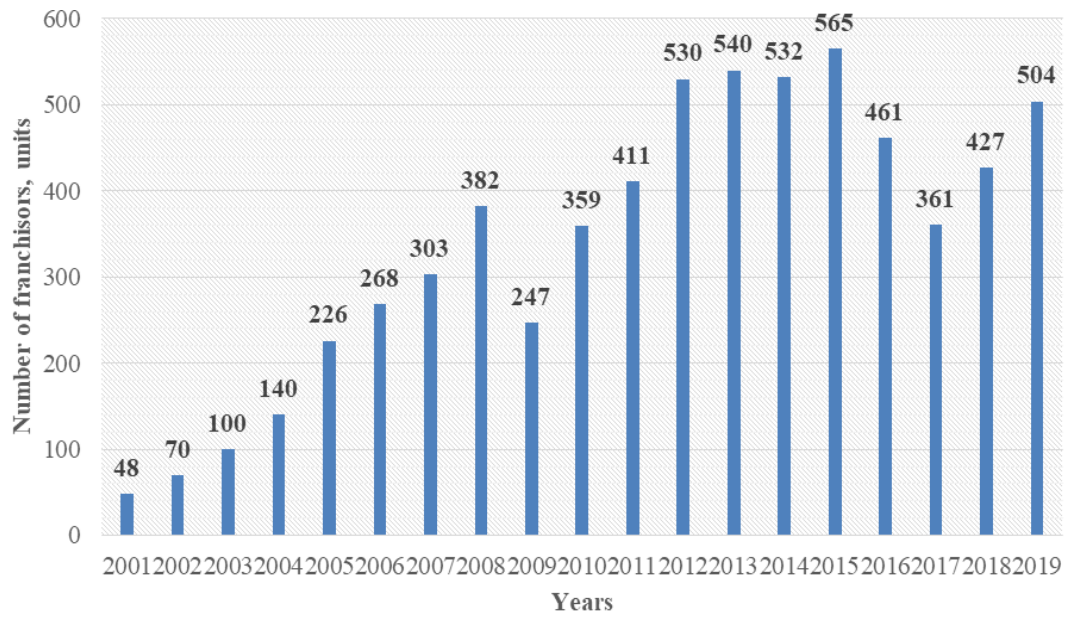

Figure 1. Dynamics of the number of franchisors in Ukraine in 2001-2019

(Source: Franchise Group Analytical Report of the Franchising Market, 2021)

Primary data are summarized and presented using a graphical method to illustrate the results of the study and improve the level of perception of information. Despite the frequent cases of non-fulfilment of obligations by the participants of the franchising agreement in tourism, as well as dishonest compliance with the legislation in the field of 
intellectual property, which occur in Ukraine, the franchising market has a positive upward trend (Figure 1). The dominant role of domestic franchisors in Ukraine has led to the dependence of the profitability of this business model on the financial and economic crises that have occurred in the country in recent years (Figure 2). II (2008-2009) and III (2014) economic

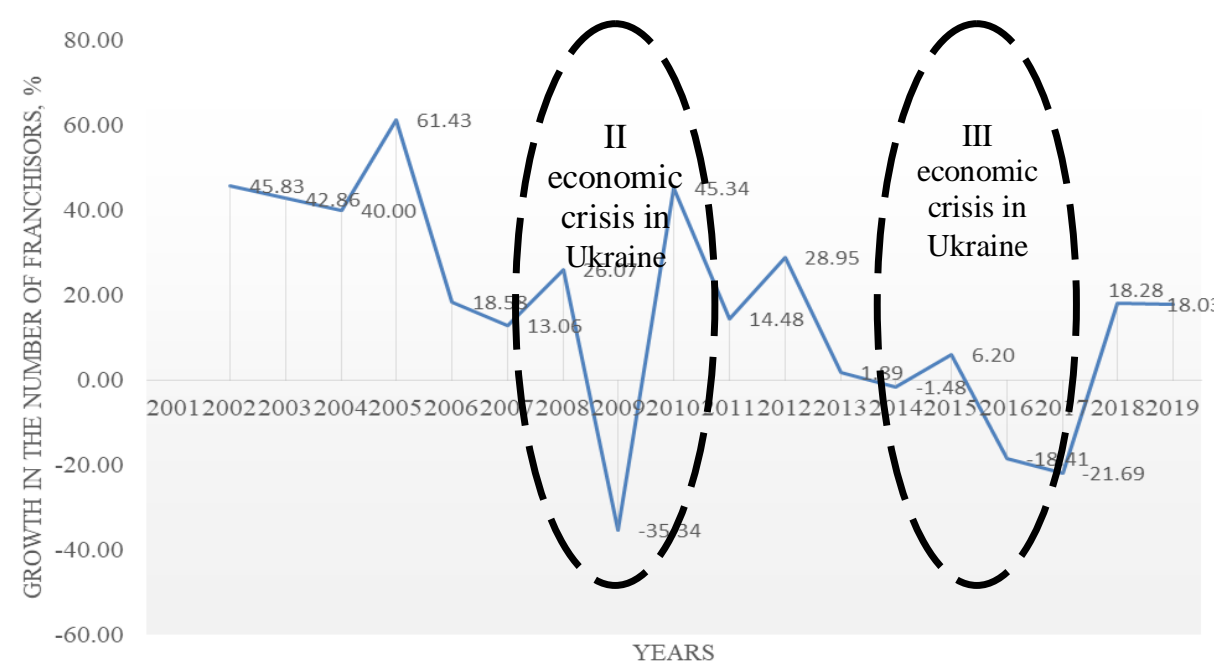

Figure 2. Dynamics of growth in the number of franchisors in

Ukraine in 2001-2019 (Source: calculated on the basis of Figure 1)
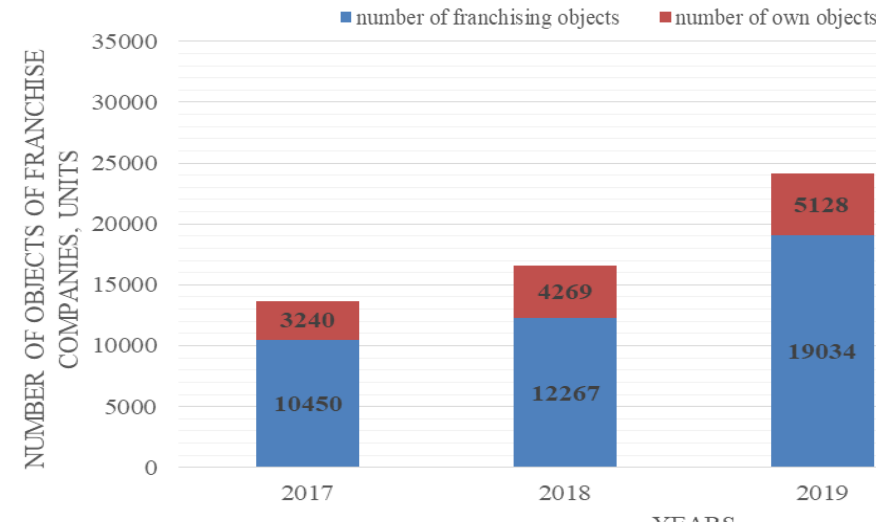

YEARS

Figure 3. The ratio of the number of franchising to its own objects in franchising companies in Ukraine in 2017-2020 (Source: Franchise Group. Analytical Report of the Franchising Market, 2021) standards and a critical assessment of

the practice of accounting for franchising by tourism enterprises in Ukraine (Figure 4).The model provides for the redistribution of assets (franchise and cash in the form of lump sums and periodic contributions) and liabilities (receivables and payables using regulatory accounts of income and expenses of previous periods to normalize payments for franchising, occurring at different times) end-users - franchisors and franchisees of the most relevant and reliable information for management decisions.

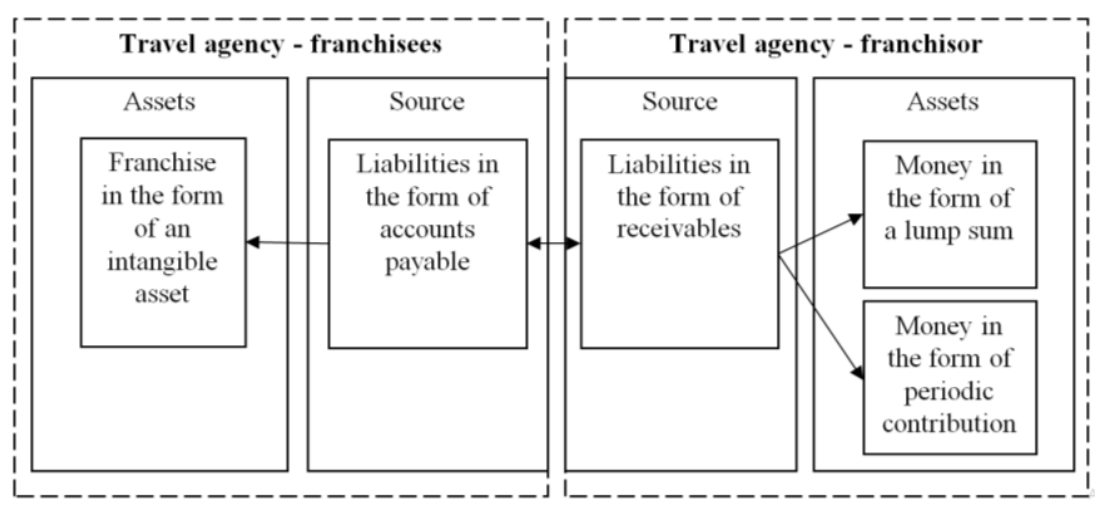

Figure 4. Methodological basis of reflection in accounting in

Ukraine of settlements between tourist enterprises on franchising operations (Source: developed by authors)

- the possibility of placing a corporate sign and/or lightbox; crises were characterized, among other things, by the bankruptcy of enterprises and dismissal of At the same time, cooperation and established business relations with franchisees allowed franchisors to reach their previous capacities as quickly as possible during several post-crisis years and stabilize the ratio of their own and franchising facilities (Figure 3). The increase in the popularity of travel franchising in Ukraine was not least due to the increase in the efficiency of operational network management and business control, which is ensured by high-quality information exchange in the franchisor-franchisee system. A significant amount of such information is processed using accounting. To reflect in the accounting of business transactions related to franchising activities, the method of double-entry with the use of sub-accounts of the secondorder to detail information flows and increase the relevance of data to be used by managers of tourist enterprises of Ukraine. The research methodology involves the use of accounting and reporting procedures by the National Accounting Regulations (Standards) of Ukraine, developed by international accounting 
- design of the premises according to the requirements of the corporate style of the franchisor;

- availability of all necessary furniture, office equipment and telecommunications;

- availability of managers with mandatory experience and knowledge of major tourist destinations;

- presence in the staff of an accountant and a system administrator (possibly on a part-time basis);

- compliance with service standards and corporate dress code (if any);

- implementation of sales plans;

- staff certification and regular training (seminars, training, etc.);

- official registration as a legal entity with a type of activity in the field of tourism, the presence of a bank guarantee, a current account in a bank and the seal of the enterprise;

- payment of the entrance fee and monthly payments (royalties).

As you can see, most of these requirements are formed based on the corporate vision of the business of the franchisor, based on the experience of previous successfully implemented tourism projects.

Last but not least, the franchisor is interested in an effectively established system of information exchange using an internal reporting mechanism based on realistic credentials to assess the profitability of a network entity.

Understanding the concept of "franchising" as an economic category has a direct impact on the methodology of accounting for related transactions. In many scientific studies, franchising is seen as a strategy to ensure the company's competitive advantage in the market through business cooperation (Alon, 2004; Altinay et al., 2013; Ribeiro and Akehurst, 2014; Dube et al., 2020; Orgonáš and Rehák, 2020; Sun and Lee, 2021) or a means of increasing the economic value of the firm through conducting special business activities (Aliouche and Schlentrich, 2009; Koh et al., 2009; Moon and Sharma, 2014; Choi et al., 2018; Kim and Lee, 2020). Economic thought has developed dozens of definitions of this term, which characterize it from different points of view (Figure 5).

Franchising as a deal
-A franchise agreement is a legal document, the subject of which is the relationship that
arises between the parties in the process of transfer and use of the franchise. The latter,
as well as royalties, fees to the advertising fund, penalties, etc., defined in the
agreement, are the objects of accounting

Franchising as a special type of business activity

-For the franchisor - this is part of the operating activities, for simple (non-diversified) franchisees - this is, in fact, the main activity. If necessary, accounting should provide management with information to make decisions about the profitability of its maintenance

Franchising as a marketing system
- This interpretation, in essence, allows us to consider the income and expenses
associated with the franchise relationship in terms of their sales nature

Franchising as a form of business cooperation (system of relations)

- Accounting should be structured in such a way as to aggregate and provide managers with high-quality debt information regarding the relationship between the franchisor and the franchisee.

Franchising as a form of organization and doing business

- Because any change in the business processes of the recipient company in one way or another affects the accounting process, the accounting department of the franchisee should be prepared for ongoing cooperation with the franchisor under the signed agreement, in particular in terms of accountability. activity, state of debt, use of transferred assets, settlements on the advertising fund, etc.

Franchising as a way of delivering products and services to end consumers

- The logistical essence of franchising has an impact on the construction of analytical accounting accounts for information support of the "producer-consumer" system, taking into account the existence of intermediary structures

Figure 5. Influence of polymorphism of nature of franchising on construction of system of accounting of the enterprises of a tourist franchising network (Source: developed by authors)

objective basis for an effective decision support system in the field of tourism franchising.
In our opinion, the method of accounting for the relationship between the franchisor and the franchisee should be considered in seven interrelated aspects:

1) the place of the franchising agreement as a separate object of accounting in the management system;

2) accounting for franchise accounting;

3) accounting for the accrual and payment of the lump sum and the periodic part of the royalty;

4) accounting for mutual settlements that arise in the process of transferring equipment by the franchisor, know-how, intellectual property, etc. to the franchisee;

5) accounting for goodwill;

6) recognition and write-off of expenses related to the payment of royalties, etc. franchising costs;

7) accounting for income tax and VAT arising in the course of transactions in the system of franchising relationships.

Transformation on this basis of accounting from a simple registrar of business transactions to a powerful tool for information support of the enterprise management system is a necessary factor for the success of any business project, including and the creation of a travel franchising network and provides for the effective redistribution of information flows in the system of accounts using the method of doubleentry (Table 1). The use of a system of accounts with a source of assets in the form accounts of payable and redistribution of accounting information through income/ expense accounts of future periods will form the most 


\section{DISCUSSION}

When forming the methodological basis of accounting for franchising operations in the tourism business should be based on the following assumptions:

1. Debatable recognition of the franchise (business methods, trademark, technology, etc.) as an intangible asset in the accounting of the franchisee. This approach is proposed in the work of several domestic scientists (Pankova and Kubatkina, 2009; Lysa and Andrushko, 2013; Hyk et al., 2021), but may seem quite contradictory both because of the inability to reliably determine the value of such intangible assets and because of the lack of exclusive (right to use them alienation) (from the point of view of such economists as N.A. Boreyko (Boreyko, 2010), etc.).

Table 1. Correspondence of accounts of franchise and royalty transactions at the franchisor and franchisee (Source: author's generalization)

\begin{tabular}{|c|c|c|}
\hline \multirow[t]{2}{*}{ The content of the business transaction } & \multicolumn{2}{|c|}{ Correspondence of accounts } \\
\hline & D-t & $\mathrm{C}-\mathrm{t}$ \\
\hline \multicolumn{3}{|c|}{ I. Accounting for a franchise as an object of a franchising agreement } \\
\hline \multicolumn{3}{|c|}{ In the franchisee: } \\
\hline $\begin{array}{l}\text { The franchisee's expenses for purchasing a franchise from the } \\
\text { franchisor enterprise in the amount of a one-time contribution } \\
\text { are reflected }\end{array}$ & $\begin{array}{l}154 \text { "Acquisition (creation) of } \\
\text { intangible assets" }\end{array}$ & $\begin{array}{l}685 \text { "Settlements with other } \\
\text { creditors" }\end{array}$ \\
\hline Introduction of intangible assets in the form of a deductible & 127 "Other intangible assets" & $\begin{array}{l}154 \text { "Acquisition (creation) of } \\
\text { intangible assets" }\end{array}$ \\
\hline \multicolumn{3}{|c|}{ In the franchisor: } \\
\hline $\begin{array}{l}\text { Received a one-time fee for the use of the franchise from the } \\
\text { franchisee }\end{array}$ & $\begin{array}{l}311 \text { "Accounts in national } \\
\text { currency" }\end{array}$ & 69 "Deferred income" \\
\hline \multicolumn{3}{|c|}{ II. Accounting for a one-time (lump sum) fee under a franchising agreement } \\
\hline \multicolumn{3}{|c|}{ In the franchisee } \\
\hline A lump-sum payment was paid for the received franchise & $\begin{array}{l}685 \text { "Settlements with other } \\
\text { creditors" }\end{array}$ & $\begin{array}{l}311 \text { "Accounts in national } \\
\text { currency" }\end{array}$ \\
\hline \multicolumn{3}{|c|}{ In the franchisor: } \\
\hline $\begin{array}{l}\text { Part of the received contribution is taken into account in the } \\
\text { calculations for the use of the franchise }\end{array}$ & 69 "Deferred income" & $\begin{array}{l}373 \text { "Calculations of accrued } \\
\text { income" }\end{array}$ \\
\hline $\begin{array}{l}\text { Inclusion in the income of the reporting period of the received } \\
\text { lump sum }\end{array}$ & $\begin{array}{l}373 \text { "Calculations of accrued } \\
\text { income" }\end{array}$ & 719 "Other operating income" \\
\hline \multicolumn{3}{|c|}{ III. Accounting for periodic fees under the franchising agreement: } \\
\hline \multicolumn{3}{|c|}{ In the franchisee (subject to granting the right to use the franchise for a limited period): } \\
\hline $\begin{array}{l}\text { Deferred expenses are recognized in the amount of periodic } \\
\text { royalties due under the terms of the franchising agreement }\end{array}$ & 39 "Deferred expenses" & 55 "Other long-term liabilities" \\
\hline $\begin{array}{l}\text { Part of long-term royalty liabilities to be repaid within } 12 \\
\text { months from the balance sheet date has been transferred to } \\
\text { current debt }\end{array}$ & 55 "Other long-term liabilities" & $\begin{array}{l}611 \text { "Current debt on long-term } \\
\text { liabilities in national currency" }\end{array}$ \\
\hline $\begin{array}{l}\text { A periodic fee has been paid under the terms of the franchise } \\
\text { agreement }\end{array}$ & $\begin{array}{l}611 \text { "Current debt on long-term } \\
\text { liabilities in national currency" }\end{array}$ & $\begin{array}{l}311 \text { "Accounts in national } \\
\text { currency" }\end{array}$ \\
\hline $\begin{array}{l}\text { The amount of the periodic royalty, which belongs to the } \\
\text { reporting period, is written off }\end{array}$ & 93 “Sales costs" & 39 "Deferred expenses" \\
\hline \multicolumn{3}{|c|}{ In the franchisee (subject to granting the right to use the franchise for an indefinite period): } \\
\hline \begin{tabular}{|l|l} 
The amount of periodic royalties is written off &
\end{tabular} & 93 "Sales costs" & $\begin{array}{l}685 \text { "Settlements with other } \\
\text { creditors" }\end{array}$ \\
\hline $\begin{array}{l}\text { A periodic fee has been paid under the terms of the franchise } \\
\text { agreement }\end{array}$ & $\begin{array}{l}685 \text { "Settlements with other } \\
\text { creditors" }\end{array}$ & $\begin{array}{l}311 \text { "Accounts in national } \\
\text { currency" }\end{array}$ \\
\hline \multicolumn{3}{|c|}{ In the franchisor (subject to a limited period of use of the franchise): } \\
\hline $\begin{array}{l}\text { The long-term debt of the franchisee on payment of the total } \\
\text { amount of periodic payments is reflected }\end{array}$ & 183 “Other receivables" & 69 "Deferred income" \\
\hline $\begin{array}{l}\text { The current debt of the franchisee to pay the franchise is } \\
\text { reflected }\end{array}$ & $\begin{array}{l}373 \text { "Calculations of accrued } \\
\text { income" }\end{array}$ & 183 "Other receivables" \\
\hline $\begin{array}{l}\text { Received a periodic payment for the franchise, which relates to } \\
\text { the reporting period }\end{array}$ & $\begin{array}{l}311 \text { "Accounts in national } \\
\text { currency" }\end{array}$ & $\begin{array}{l}373 \text { "Calculations of accrued } \\
\text { income" }\end{array}$ \\
\hline Accrued periodic income from the franchise & 69 "Deferred income" & 719 "Other operating income" \\
\hline \multicolumn{3}{|c|}{ In the franchisor (subject to unlimited use of the franchise): } \\
\hline \begin{tabular}{|l|l} 
Accrued periodic income from the franchise &
\end{tabular} & $\begin{array}{c}373 \text { "Calculations of accrued } \\
\text { income" }\end{array}$ & 719 "Other operating income" \\
\hline Received a periodic payment for the franchise & $\begin{array}{l}311 \text { "Accounts in national } \\
\text { currency" }\end{array}$ & $\begin{array}{l}373 \text { "Calculations of accrued } \\
\text { income" }\end{array}$ \\
\hline \multicolumn{3}{|c|}{ IV. Depreciation of the franchise in the franchisee } \\
\hline $\begin{array}{l}\text { Amortization of intangible assets in the form of a franchise has } \\
\text { been accumulated }\end{array}$ & 93 "Sales costs" & $\begin{array}{l}133 \text { "Accumulated amortization } \\
\text { of intangible assets" }\end{array}$ \\
\hline
\end{tabular}

The International Accounting Standard 38 "Intangible Assets" does not provide an unambiguous answer, in paragraph 9 of which the franchise is given as an example of an intangible asset, but the following paragraph states: "Not all objects 
described in paragraph 9 meet the definition of an intangible asset (it is about the possibility of identification, control over the resource and the existence of future economic benefits)". However, it should be noted that in both domestic and international accounting practice, the franchise meets the main criteria for recognition of an intangible asset:

- identity - arises as a result of contractual rights regulated in the franchising agreement;

- control - the entity has the authority to obtain future economic benefits from the use of the franchise and to limit the access of others to these benefits;

- future economic benefits - the use of the franchise potentially leads to an increase in income from the sale of products or services to the franchisee;

- reliability of determination of value - compensation for the acquisition of such an asset comes to the franchisor in the form of a lump sum (forms the initial cost of the franchise in the franchisee) and periodic royalties (written off to operating expenses). That is, only the absence of a one-time payment for the acquired franchise makes it impossible to recognize it as a non-current asset.

It is important to note that the absence of an exclusive right to use a franchise cannot in itself be the reason for excluding this object from intangible assets, as indicated by some scholars, as such "exclusivity" is not a standard requirement for intangible assets.

2. The system of obligatory relations, which is formed between the franchisor and the franchisee in the aspect of accrual of one-time (lump sum) contribution and royalty (periodic service fee).

Usually, a franchising agreement is signed for more than one year, respectively, the relationship between its participants in the accrual and payment of royalties is transferred to the plane of long-term. In this case, in the case of accrual of a monthly fee regardless of the amount of income received by the franchisee, the total debt of the latter is reflected on the credit of account 55, while receivables from the franchisor are accounted for using sub-account 183.

3. Since the lump sum is paid to the franchisee (received by the franchisor) in advance in a single payment, while the benefits of using the franchise are long-term, its attribution to the costs (income) of the reporting period is gradual, equal parts, during the contract using the redistribution mechanism through the accounts of expenses (income) of future periods. An important condition, however, is the reliability of the definition of the latter.

The answer, deferred income (expense) can be recognized only if arrangements are made for "fixed" amounts of payments that do not deviate from multiple revenues received by the franchisee.

4. In the domestic specialized literature and accounting periodicals there is no uniformity in the nomenclature of subaccounts, which monitor the indicators of income and expenses of the period, which affect the process of franchising. Offered: 703 "Income from sales of works and services", 713 "Income from operating lease of assets", 719 "Other income from operating activities", 23 "Production", 903 "Cost of sold services and services", 91 "Overhead costs", 93 "Sales costs". In our opinion, in contrast to the rational and methodologically sound use of sub-account 719 to reflect the income received by franchisors in the case of royalties, while to account for the costs of franchisees under franchising agreements-account 93 and subaccount 704. Note that the franchisor's income from franchising operations may include not only the entrance fee and periodic royalties, but also income in the form of rent and lease payments; contributions to the advertising fund; markup on the cost of goods and materials supplied to franchisees; payment for various related services (eg, related to the selection of premises and equipment, mediation between franchisees and financial institutions), etc. This should be reflected in the system of analytical accounts of the franchisor.

5. According to the current tax rules set out in the Tax Code of Ukraine, the payment of royalties in cash is not subject to VAT. At the same time, the income in the form of royalties is taken into account when calculating the object of corporate income tax.

\section{CONCLUSION}

Franchising can become one of the effective methods of doing business in tourism, provided the creation of mutually beneficial partnerships between enterprises of the potential network in Ukraine. The main advantages of franchising business for the franchisor are the expansion of the scale and geography of the business, as well as additional income from royalties, while the franchisee expects to save their financial resources, increase competitiveness and use in business "promoted" brand. To reduce their business risks, tour operators-franchisors put forward to potential franchise receivers several requirements, which are reduced to geographical-locational, legal-financial, technical and personnel. Understanding the essence of the concept of "franchising" as an agreement, a special type of business, marketing system, forms of business cooperation (system of relations), forms of organization and business, delivery of products and services to end-users has a significant impact on accounting methodology of franchising. The reflection of franchising operations in the accounts and the accounting registers is the basis for the proper organization of accounting processes in both the franchisor and the franchisee. Our study allows us to draw the following conclusions:

1) the franchise is the object of intangible assets, primarily because it meets the conditions of identification, controllability, availability of future economic benefits and the reliability of the determination of value;

2) since the settlements between the franchisor and the franchisee are long-term and stretched over time, there is an objective need to use the accounts of income and expenses of future periods to comply with the fundamental principle of their accrual and compliance. For this purpose, in the practice of Ukrainian companies, accounts 39 "Deferred expenses" and 69 "Deferred income" are used. It is established that when accruing and paying/receiving a lump sum and periodic contributions, as well as the accumulation of depreciation of the franchise in the franchise should take into account the period during which the franchise agreement; 
3) the most informative to reflect the income and expenses of the period that arises in the process of franchising by tourism enterprises, as well as relevant to the laws of Ukraine accounts are 719 "Other income from operating activities" - to reflect income received by the franchisor in the form of royalties, 704 "Deductions from income" - to account for royalties as a percentage of income, 93 "Sales costs" - to account for the costs of the franchisee under the franchise agreement (accounting for "fixed" amounts of payments). They are the basis for the construction of accounting records to establish the results of financial activities of franchisees and franchisees and allow you to objectively determine the profitability of franchising in the tourism business.

\section{REFERENCES}

Aliouche, E.H., \& Schlentrich, U. (2009). Does franchising create value? An analysis of the financial performance of US public restaurant firms. International Journal of Hospitality \& Tourism Administration, 10 (2), 93-108. https://doi.org/10.1080/15256480902850943

Alon, I., Apriliyanti, I.D., \& Parodi, M.C.H. (2021). A systematic review of international franchising. Multinational Business Review, 29 (1), 43-69. https://doi.org/10.1108/MBR-01-2020-0019

Alon, I. (2004). Global franchising and development in emerging and transitioning markets. Journal of Macromarketing, 24 (2), 156167. https://doi.org/10.1177/0276146704269320

Altinay, L., Brooks, M., \& Aktas, G. (2013). Selecting franchise partners: Tourism franchise approaches, processes and criteria. Tourism Management, 37, 176-185. https://doi.org/10.1016/j.tourman.2013.01.016

Bardash, S.V. (2021). Контроль франчайзингових відносин у туристичному бізнесі [Control of franchising in the tourism business]. Scientific Bulletin of Kherson State University. Series Economic Sciences, 41, 17-21 (in Ukrainian). https://doi.org/10.32999/ksu2307-8030/2021-41-3

Boreyko, N.A. (2010). Проблемы и пути совершенствования учета разовых франчайзинговых платежей у франчайзи [Рroblems and ways of accounting improving for one-time franchising payment in franchise]. Problems of Theory and Methodology of Accounting, Control and Analysis, 17 (2), 19-24 (in Russian). https://doi.org/10.26642/pbo-2010-2(17)-91-99

Bunea-Bontas, C.A., \& Petre, M. (2009). Franchise in Romanian tourism. O\&M: The Firm as a Nexus of Contracts (Boundaries of the Firm) eJournal. https://mpra.ub.uni-muenchen.de/18136/1/MPRA_paper_18136.pdf. https://doi.org/10.2139/ssrn.1492023

Choi, S., Lee, S., Choi, K., \& Sun, K.A. (2018). Investment - cash flow sensitivities of restaurant firms: A moderating role of franchising. Tourism Economics, 24 (5), 560-575. https://doi.org/10.1177/1354816618759201

Combs, J.G., Ketchen, Jr., D.J., Shook, C.L., \& Short, J.C. (2011). Antecedents and consequences of franchising: Past accomplishments and future challenges. Journal of Management, 37 (1), 99-126. https://doi.org/10.1177/0149206310386963

Czakon, W. (2012). Business format franchise in regional tourism development. Anatolia: An International Journal of Tourism and Hospitality Research, 23 (1), 107-117. https://doi.org/10.1080/13032917.2011.653635

Diez de Castro, E.C., Rondan-Cataluna, F.J., \& Navarro-Garcia, A. (2004). Research on franchising. In: $13^{\text {th }}$ World Business Congress of the International Management Development Association (IMDA), 14-18 Jul 2004, Maastricht, The Netherlands.

Dube, B., Mara, C., \& Ntimane, V. (2020). Perceptions of franchise stakeholders on trust in franchising relationships. African Journal of Hospitality, Tourism and Leisure, 9 (1), 1-12.

Elango, B. (2019). A bibliometric analysis of franchising research (1988-2017). The Journal of Entrepreneurship, 28 (2), $223-249$. https://doi.org/10.1177/0971355719851897

Gallini, N.T., \& Lutz, N.A. (1992). Dual distribution and royalty fees in franchising. The Journal of Law, Economics \& Organization, 8 (3), 471-501.

Ghani, M.F.A., Hizam-Hanafiah, M., Isa, R.M., \& Hamid, H.A. (2021). Systematic literature review: The trend on franchising strategy. International Journal of Entrepreneurship, 25 (5), 1-18.

Hyk, V., Vysochan, O., \& Vysochan, O. (2021). Modeling the options for accounting for the innovation costs of industrial enterprises in Ukraine. Intellectual Economics, 15 (1), 88-103. https://doi.org/10.13165/IE-21-15-1-06

Kaufmann, P.J., Gordon, R.M., \& Owers, J.E. (2000). Alternative profitability measures and marketing channel structure: The franchise decision. Journal of Business Research, 50, 217-224. https://doi.org/10.1016/s0148-2963(99)00035-1

Kieso, D.E., Weygandt, J.J., \& Warfield, T.D. (2011). Intermediate Accounting: IFRS Edition. John Wiley and Sons, Inc.

Kim, B., \& Lee, S. (2020). The impact of material and immaterial sustainability on firm performance: The moderating role of franchising strategy. Tourism Management, 77, 103999. https://doi.org/10.1016/j.tourman.2019.103999

Koh, Y., Lee, S., \& Boo, S, (2009). Does franchising help restaurant firm value? International Journal of Hospitality Management, 28 (2), 289-296. https://doi.org/10.1016/j.ijhm.2008.10.001

Kravchuk, N., \& Spivak, S. (2017). Економічний зміст та облікове відображення франчайзингу [Economic content and accounting of franchising]. Galician Economic Journal, 2 (53), 103-110 (in Ukrainian). https://doi.org/10.33108/galicianvisnyk_tntu2017.02.103

Kuryshko, O. (2014). Франчайзинг у туризмі: документальне оформлення та облік [Franchising in tourism: documentation and records]. Accountancy, 8 (1099), 64-69 (in Ukrainian).

Luangsuvimol, T., \& Kleiner, B.H. (2004). Effective franchise management. Management Research News, 27 (4/5), 63-71. https://doi.org/10.1108/01409170410784482

Lysa, O., \& Andrushko, R. (2013). Обліково-правові аспекти франчайзингу [Accounting-law aspects of franchising]. Journal of Lviv National Agrarian University. Economics of AIC Series, 20 (1), 200-205 (in Ukrainian).

Makarovych, V., Klimko, T., \& Balog, S. (2015). Франчайзинг: обліковий аспект [Franchising: accounting]. Bulletin of Donetsk National University. Series C. Economics and Law, 1, 225-228 (in Ukrainian).

Makoviychuk, O.V. (2013). Обліково-класифікаційний підхід франчайзингових операцій [Accounting and classification approach of franchising operations]. Bulletin of Zhytomyr Polytechnic State University. Economics, Management and Administration, 1 (63), 129132 (in Ukrainian). https://doi.org/10.26642/jen-2013-1(63)-129-132

Marik, P.E., \& Komlichenko, D.S. (2014). Аналіз формування фінансових результатів 1C: Франчайзі [Analysis of the financial results of the 1C: franchisee]. Economics: Time Realities, 4 (14), 157-163 (in Ukrainian).

Momot, L.V., \& Ovdiy, O.V. (2010). Бухгалтерський облік франшизи [Franchise accounting]. Scientific Works of National University of Food Technologies, 35, 173-177 (in Ukrainian).

Moon, J., \& Sharma, A. (2014). Franchising effects on the lodging industry: Optimal franchising proportion in terms of profitability and intangible value. Tourism Economics, 20 (5), 1027-1045. https://doi.org/10.5367/te.2013.0336 
Nurwulan, L.L., Noch, R.M., \& Kurniawan, E. (2013). Understanding accounting franchise, guidance by franchisor and going concern of franchise company in Bandung. In: $6^{\text {th }}$ International Seminar on Industrial Engineering and Management, Batam, Indonesia.

Orgonáš, J., \& Rehák, R. (2020). Franchising - paradigm of the enterprise in the $21^{\text {st }}$ century. Management Studies, 8 (2), $110-115$. https://doi.org/10.17265/2328-2185/2020.02.002

Pankova, S.V., \& Kubatkina, G.A. (2009). Понятие и классификация гостиничных услуг как объекта управленческого учета [Concept and classification of hotel services as an object of management accounting]. Vestnik OSU, 2, 90-94 (in Russian).

Ribeiro, D., \& Akehurst, G.P. (2014). Franchising in services. The Service Industries Journal, 34 (9-10), 751-756. https://doi.org/10. 1080/02642069.2014.905923

Romanchuk, K., Ostapyuk, N., \& Kotenko, I. (2014). Особливості організації франчайзингової діяльності в Україні та їх вплив на об'єкти бухгалтерського обліку [Features of franchising activity in Ukraine and their impact on the subject of accounting]. Scientific Bulletin of Mukachevo State University. Economics Series, 2 (2), 148-156 (in Ukrainian).

Rosado-Serrano, A., Paul, J. \& Dikova, D. (2018). International franchising: A literature review and research agenda. Journal of Business Research, 85, 238-257. https://doi.org/10.1016/j.jbusres.2017.12.049

Sadeh, F., \& Kacker, M. (2020). Performance implications of using signaling and screening for expanding interfirm business networks: Evidence from franchising. Industrial Marketing Management, 88, 47-58. https://doi.org/10.1016/j.indmarman.2020.04.008

Serpeninova, Y.S. (2014). Франчайзинг: сутність та порядок відображення в обліку [Franchising: essence and accounting procedure]. Herald of Khmelnytskyi National University. Economic Sciences, 1, 256-260 (in Ukrainian).

Shevchuk, E.O. (2017). Обліково-аналітичне забезпечення аудиту ділового партнерства франчайзингової туристичної мережі [Accounting and analytical providing audit of business partnership of the franchising tourism network]. International Humanitarian University Herald. Economics and Management, 27, 139-143 (in Ukrainian).

Sisea, D.G. (2013). Coordinates the operations of the franchise and the implications in the field of accounting. Working Papers 17. Ecological University of Bucharest, Department of Economics. Available at: http://ueb.ro/RePEc/eub/wpaper/eub-2013/2013-17.pdf

Sun, K.A., \& Lee, S. (2021). How does franchising alter competition in the restaurant industry? Journal of Hospitality and Tourism Management, 46, 468-475. https://doi.org/10.1016/j.jhtm.2021.02.002

Tsenkler, N., \& Nemesh, М. (2019). Франчайзингові операції: облікові аспекти [Franchising operations: Accounting aspects]. Black Sea Economic Studies, 48 (3), 188-193 (in Ukrainian). https://doi.org/10.32843/bses.48-97

Tsyutsyak, A. (2014). Сучасний стан обліку та оподаткування франчайзингових операцій підприємств ресторанного господарства [Modern state of accounting and taxing of franchising in a restaurant business]. Bulletin of Taras Shevchenko National University of Kyiv. Economics, 10 (162), 95-101 (in Ukrainian).

Varotto, L.F., \& Aureliano-Silva, L. (2017). Evolution in franchising: Trends and new perspectives. Revista Eletrônica de Negócios Internacionais: Internext, 12 (3), 31-42. https://doi.org/10.18568/1980-4865.12331-42

Vysochan, O.S. (2014). Організація приватного партнерства в туристичному секторі на засадах франчайзингу [Organization of the private partnership in the tourism sector, based on the principles of franchising]. Scientific Bulletin of Kherson State University. Economic Sciences Series, 7 (5), 114-117 (in Ukrainian).

Vysochan, O., Vysochan, O., Hyk, V., \& Hryniv, T. (2021). Attributive-spatial tourist clusteration of regions of Ukraine. GeoJournal of Tourism and Geosites, 35 (2), 480-489. https://doi.org/10.30892/gtg.35228-675

Vysochan, O.S., Vysochan, O.O., Yasinska, A.I., \& Hyk, V.V. (2021). Selection of accounting software for small and medium enterprises using the fuzzy topsis method. TEM Journal, 10 (3), 1348-1356. https://doi.org/10.18421/TEM103-43

Zeff, S.A. (2011). Accounting for initial franchise fee revenue: When a journal article in 1970 constituted GAAP in the eyes of the SEC. Research in Accounting Regulation, 24 (1), 1-5. https://doi.org/10.1016/j.racreg.2011.12.001

*** Franchise Group (2021). Analytical Report of the Franchising Market. https://franchisegroup.com.ua/about-company/franchising/

Article history: Received: 17.08.2021 Revised: 06.11.2021 Accepted: 31.12.2021 Available online: 19.01.2022 